\title{
USING EVA METHOD TO ASSESS ACHIEVEMENT OF BEJ REGISTERED RETAIL TRADE COMPANY
}

\author{
Haryadi Sarjono \\ Management Department, Economic and Business Faculty, Bina Nusantara University \\ Jln. K.H. Syahdan No. 9, Palmerah, Jakarta Barat 11480, Indonesia \\ haryadi_s@binus.edu
}

\begin{abstract}
This research aims to evaluate the the achievement in terms of the company finance, on whether it adds value or not to shareholders and investors) in generating profit on top of used capital or normally mentioned as the method of EVA. This research was carried out against 10 retail trade companies that registered in BEJ during the finance year of 2005 by using the documentary or secondary data obtained from the Centre of the Pasar Modal Reference (PRPM) in the Building of Bursa Efek Jakarta (BEJ). Evaluation results suggested 6 companies for future investment.
\end{abstract}

Keywords: EVA method, the achievement, retail company, Jakarta Stock Exchange

\begin{abstract}
Penelitian ini bertujuan untuk mengkaji kinerja atau pencapaian dalam lingkup finansial perusahaan, apakah menambah nilai bagi para pemilik saham dan investor dalam menghasilkan keuntungan di atas modal yang digunakan atau umumnya disebut metode EVA. Penelitian ini dilaksanakan terhadap 10 perusahaan dagang ritel yang terdaftar di BEJ selama tahun financial 2005 dengan menggunakan data documenter atau sekunder yang didapat dari Pusat Referensi Pasar Modal (PRPM) yang berada di Bangunan Bursa Efek Jakarta. Hasil pengkajian menyarankan investasi untuk 6 perusahaan.
\end{abstract}

Kata kunci: Metode Eva, kinerja/pencapaian, perusahaan ritel, BEJ 


\section{INTRODUCTION}

\section{Background}

Each company aims to have long-term investments, in order to obtain the profit for the company. Task given by the management to the company is to maximize the value of the company and therefore maximizing wealth of shareholders. If a company wishes to invest, the recovery rate that will be received from this investment must give a bigger value than the initial investment, and therefore the objectives set by the company could be reached in obtaining maximum profit. Until now the method used in analyzing achievement of the company is by knowing the ratio of finance, such as return on assets, return on equity and the margin profit. This approach has for a long time been utilised by the analysts, due to simplicity in calculation and easy to understand. However in the evaluation of the achievement of finance should not see just how far the level of the profit received by a company, but also see whether this company received bigger profit than used capital. Economic Value Added (EVA) is an indicator from an investment that simply could be interpreted as the operation profit after the tax (After Tax Operating Income) that deducted with total capital cost (The Total of Cost of Capital), where the total cost was counted by means of multiplying level of the capital cost with total invested cost.

\section{Research Problem}

Based on the background analysis, several problems are discussed in this research, namely: 1) How much is the EVA values (Economic Value Added) and how big is the finance achievement of 10 retail trade companies registered in BEJ, during 2005, 2) how the decision comparison of investment by using Eva method and ROA (Return ounce Assets) to 10 retail trade companies that were registered in BEJ during 2005, 3) how Finance Manager's analysis with Eva method towards the recovery rate that was hoped for by the investor to 10 retail trade companies that were registered in BEJ in the year 2005

\section{Research Purposes}

As for the aim of this research of being: 1) to evaluate Eva and measured the achievement of retail finance of the trade company that was registered in BEJ during 2005. 2) to see the comparison of investment decision by using Eva method and ROA for 10 registered retail trade companies in BEJ during 2005. 3) to evaluate analysis of Finance Manager with EVA method towards the recovery rate wished by the investor for 10 registered retail trade companies in BEJ during 2005.

\section{Literature Review}

\section{The Meaning of Financial Statment}

The understanding of the Report on Finance (IAI, 2004:2) was part of the process of finance reporting. The report on complete finance includes balance sheet, profit and loss report, the report on change of equity, cash flow report, and finance report notes. whereas according to Weston and Copeland (2002:17) the definition of the Report on Finance that is: the report on finance or financial statement containing information on achievement of the company in the past and could give the guidance for the determination of the policy in future periods. 


\section{The Meaning of Bankrupt}

legal manner.

Bankruptcy is the inability of the individual or an organisation to pay their creditors stated in a

Table 1 The Definition of Bankruptcy/ Failure

\begin{tabular}{|c|c|c|}
\hline Name & Term & Definition \\
\hline $\begin{array}{l}\text { Altman } \\
(1973)\end{array}$ & Bankruptcy & $\begin{array}{l}\text { The company that legally bankrupt, good was } \\
\text { placed under the trusteeship or was guaranteed by } \\
\text { his right to be reorganized as supervised by } \\
\text { National Bankruptcy Act }\end{array}$ \\
\hline $\begin{array}{l}\text { Beaver } \\
(1967)\end{array}$ & Failure & $\begin{array}{l}\text { The inability of the company to pay their financial } \\
\text { obligation when being due or being operationally } \\
\text { interpreted as the company that experienced the } \\
\text { bankruptcy, the failure paid the interest and the } \\
\text { subject of the debenture, the balance negative the } \\
\text { estimate of the bank, the share dividend of the } \\
\text { priority that was not paid. }\end{array}$ \\
\hline $\begin{array}{l}\text { Blum } \\
(1974)\end{array}$ & Failure & $\begin{array}{l}\text { Incidents that showed the inability to pay his debt } \\
\text { when being due that caused the company to } \\
\text { experience the bankruptcy, or to cause the } \\
\text { occurrence of the explicit agreement with the } \\
\text { creditor to reduce the debt. }\end{array}$ \\
\hline $\begin{array}{l}\text { Deakin } \\
(1972)\end{array}$ & Failure & $\begin{array}{l}\text { The company that experienced the bankruptcy, the } \\
\text { insolvency, or was liquidated for the interests of the } \\
\text { creditor. }\end{array}$ \\
\hline $\begin{array}{l}\text { Foster } \\
(1986)\end{array}$ & Bankruptcy & $\begin{array}{l}\text { A legal incident that really was influenced by the } \\
\text { action banker and the creditor }\end{array}$ \\
\hline $\begin{array}{l}\text { Kunt } \\
(1989)\end{array}$ & De Facto & $\begin{array}{l}\text { The stopping of autonomy of the operation that was } \\
\text { ordered by the regulator }\end{array}$ \\
\hline
\end{tabular}

Source: Karels \& Praskah (1987)

\section{Analysis of Discriminants}

Emery, Finnerty, dan Stowe (2004:844) suggested concerning the discriminant analysis as follows, the form and the discriminant function is $\mathrm{Z}=\mathrm{V} 1 \mathrm{X} 2+\mathrm{V} 2 \mathrm{X} 2+. .+\mathrm{VnXn}$. The discriminant function changed the ratio of finance that was independent in a discriminant single score or Z-Score. Z-Score later is used to classify the company in the category "bankrupt" or not "bankrupt". In this equality V1, V2, et cetera was the coefficient diskriminan and X1, X2, et cetera was the ratio of finance.

\section{The Application of The Altman Model Discriminant Analysis}

The Model Altman Discriminant analysis experienced the development totalling three times, that is Z-Score the first model (Z-Score), Z-Score revision (Z-Score), and Z-Score the modification (ZScore). In this case, the empirical testing of Z-Score is used not only to predict whether one emitent the debenture will be bankrupt or not, but also for the prediction of the possibility of failing to pay from one emitent to the debenture in two years afterwards. The prediction of the bankruptcy was considered as the same as the prediction of failing payment on the basis of that failing payment is part of the financial difficulty where this is early signs of the bankruptcy of a company. 


\section{RESEARCH METHOD}

Type of Data used is documentary. Documentary data contains what and when an activity or the transaction, as well as whoever was involved in an incident (Indrianto dan Supomo, 2002, p.146). In this research, the type of data kind used is data about the report on the company's finance, that is the balance and the profit and loss report on retail of the trade company during 2005. The source of the research data that was used was the secondary data. The secondary data was the source of the research data that was received by the researcher in a manner indirectly about the intermediary's media (was received and recorded by the other side). In this research, the source of the research data is obtained from the Centre of the Pasar Modal Reference (PRPM) in the Jakarta Stock Exchange Building.

\section{RESULTS AND DISCUSSION}

\section{Calculation Based on EVA Method}

Based on the data received from BEJ, results of calculations are as shown in Table 2 to 11 .

Table 2 EVA calculation of PT RIMO CATUR LESTARI Tbk and its Subsidiary Companies per December 312005 (In Rupiah)

\begin{tabular}{cccccc}
\hline \multirow{2}{*}{ YEAR } & NOPAT & Invested Capital & WACC & Capital Charges & EVA \\
\cline { 2 - 6 } & $\mathbf{( 1 )}$ & $\mathbf{( 2 )}$ & $\mathbf{( 3 )}$ & $\mathbf{( 4 )}=\mathbf{( 2 ) \times ( 3 )}$ & $\mathbf{( 5 )}=\mathbf{( 1 )}-\mathbf{( 4 )}$ \\
\hline 2005 & $(2.990 .590 .013,00)$ & $66.728 .707 .842,00$ & $1.510 \%$ & $1.007 .770 .310,18$ & $(3.998 .360 .323,18)$ \\
\hline
\end{tabular}

Source: Processed data from Financial Statement of PT RIMO CATUR LESTARI Tbk and its subsidiary companies

This Eva conduct the existence destruction thought (value destruction) or in other words that the value of the company decreased as resulting from the recovery rate that was produced lower than the recovery rate that was demanded by the investor, that is of Rp. (3,998,360,323.18).

Table 3 EVA calculation of PT RAMAYANA LESTARI SENTOSA Tbk and its Subsidiary Companies per December 312005 (In Rupiah)

\begin{tabular}{|c|c|c|c|c|c|}
\hline Y & NOPAT & Invested Capital & WACC & Capital Charges & EVA \\
\hline 1大at & (1) & (2) & (3) & $(4)=(2) \times(3)$ & $(5)=(1)-(4)$ \\
\hline 2005 & $315.981 .000 .000,00$ & 1.883.297.000.000,00 & $5.382 \%$ & $101.353 .210 .000,00$ & 214.627.790.000,00 \\
\hline
\end{tabular}

Source: Processed data from Financial Statement of PT RAMAYANA LESTARI SENTOSA Tbk and its subsidiary companies

Table 2 shows that the company succeeded in creating added value for the owner of capital, in accordance with the aim of maximising the value of the company or increasing the investor's prosperity, that is of Rp. 214,627,790,000.00.- 
Table 4 EVA calculation of PT MITRA ADIPERKASA Tbk and its Subsidiary Companies per December 312005 (In Rupiah)

\begin{tabular}{cccccc}
\hline \multirow{2}{*}{ Year } & NOPAT & Invested Capital & WACC & Capital Charges & EVA \\
\cline { 2 - 6 } & $\mathbf{( 1 )}$ & $\mathbf{( 2 )}$ & $\mathbf{( 3 )}$ & $\mathbf{( 4 )}=(\mathbf{2}) \mathbf{x}(\mathbf{3})$ & $\mathbf{( 5 ) = ( 1 ) - ( 4 )}$ \\
\hline 2005 & $825.403 .590,00$ & $7.069 .031 .672,00$ & $10.841 \%$ & $766.319 .085,31$ & $59.084 .504,69$ \\
\hline
\end{tabular}

Source: Processed data from Financial Statement of PT MITRA ADIPERKASA Tbk and its subsidiary companies.

Table 3 shows that the company succeeded in creating added value for the owner of capital, in accordance with the aim of maximising the value of the company or increasing the investor's prosperity, that is of Rp. 59,084,504.69.

Table 5 EVA calculation of PT METRO SUPERMARKET REALTY Tbk and its Subsidiary Companies per December 312005 (In Rupiah).

\begin{tabular}{|c|c|c|c|c|c|}
\hline \multirow{2}{*}{ Year } & NOPAT & Invested Capital & WACC & Capital Charges & EVA \\
\hline & (1) & (2) & (3) & $(4)=(2) \times(3)$ & $(5)=(1)-(4)$ \\
\hline 2005 & $6.504 .017 .145,00$ & $90.467 .030 .783,00$ & $15.581 \%$ & $14.095 .459 .992,13$ & $(7.591 .442 .847,13)$ \\
\hline
\end{tabular}

Source: Processed data from Financial Statement of PT METRO SUPERMARKET REALTY Tbk and its subsidiary companies

Table 5 shows that the value of the company decreased as resulting from the recovery rate that was produced lower than the level of return demanded by the investors, that is in the amount of Rp.

(7.591.442.847,13,-).

Table 6 EVA calculation of PT MATAHARI Putra PRIMA Tbk and its Subsidiary Companies per December 312005 (In Rupiah).

\begin{tabular}{cccccc}
\hline \multirow{2}{*}{ Year } & NOPAT & Invested Capital & WACC & Capital Charges & EVA \\
\cline { 2 - 6 } & $\mathbf{( 1 )}$ & $\mathbf{( 2 )}$ & $\mathbf{( 3 )}$ & $\mathbf{( 4 )}=\mathbf{( 2 )} \mathbf{x}(\mathbf{3})$ & $\mathbf{( 5 ) = ( 1 ) - ( 4 )}$ \\
\hline \multirow{2}{*}{2005} & $362.654 .000 .000,00$ & $3.519 .405 .000,00$ & $5.524 \%$ & $194.408 .760 .000,00$ & $168.245 .240 .000,00$
\end{tabular}

Source: Processed data from Financial Statement of PT MATAHARI PUTRA PRIMA Tbk and its subsidiary companies.

Table 6 shows that the company succeeded in creating added value for the owner of capital, in accordance with the aim of maximising the value of the company or increasing the investor's prosperity, that is of Rp. 168,245,240,000.00.-- 
Table 7 EVA calculation of PT ALFA RETAILINDO Tbk and its Subsidiary Companies per December 312005 (In Rupiah).

\begin{tabular}{cccccc}
\hline \multirow{2}{*}{ Year } & NOPAT & Invested Capital & WACC & Capital Charges & EVA \\
\cline { 2 - 6 } & $\mathbf{( 1 )}$ & $\mathbf{( 2 )}$ & $\mathbf{( 3 )}$ & $\mathbf{( 4 ) = ( 2 ) \times ( 3 )}$ & $\mathbf{( 5 ) = ( 1 ) - ( 4 )}$ \\
\hline 2005 & $47.872 .65 .655,00$ & $528.499 .669 .872,00$ & $7.280 \%$ & $38.475 .093 .066,48$ & $9.397 .561 .588,52$ \\
\hline
\end{tabular}

Source: Processed data from Financial Statement of PT ALFA RETAILINDO Tbk and its subsidiary companies.

Table 7 shows that the company succeeded in creating added value for the owner of capital, in accordance with the aim of maximising the value of the company or increasing the investor's prosperity, that is of Rp. 9,397,561,588.52.-

Table 8 EVA calculation of PT HERO SUPERMARKET Tbk and its Subsidiary Companies per December 312005 (In Rupiah).

\begin{tabular}{cccccc}
\hline \multirow{2}{*}{ Year } & NOPAT & Invested Capital & WACC & Capital Charges & EVA \\
\cline { 2 - 6 } & $\mathbf{( 1 )}$ & $\mathbf{( 2 )}$ & $\mathbf{( 3 )}$ & $\mathbf{( 4 )}=\mathbf{( 2 ) \times ( 3 )}$ & $\mathbf{( 5 ) = ( 1 ) - ( 4 )}$ \\
\hline \multirow{2}{*}{2005} & $72.466 .000 .000,00$ & $748.332 .000 .000,00$ & $10.951 \%$ & $81.947 .220 .000,00$ & $(9.481 .220 .000,00)$ \\
\hline
\end{tabular}

Source: Processed data from Financial Statement of PT HERO SUPERMARKET Tbk and its subsidiary companies.

Table 8 shows that the value of the company decreased as resulting from the recovery rate that was produced lower than the level of return demanded by the investors, that is in the amount of Rp $(9.481 .220 .000,00,-)$.

Table 9 EVA calculation of PT GREAT RIVER INTERNATIONAL Tbk and its Subsidiary Companies per December 312005 (In Rupiah).

\begin{tabular}{cccccc}
\hline \multirow{2}{*}{ Year } & NOPAT & Invested Capital & WACC & Capital Charges & EVA \\
\cline { 2 - 6 } & $\mathbf{( 1 )}$ & $\mathbf{( 2 )}$ & $\mathbf{( 3 )}$ & $\mathbf{( 4 )}=\mathbf{( 2 ) \times ( 3 )}$ & $\mathbf{( 5 ) = ( 1 ) - ( 4 )}$ \\
\hline 2005 & $94.793 .379 .952,00$ & $986.190 .083 .548,00$ & $9.336 \%$ & $92.066 .958 .677,72$ & $2.726 .421 .274,28$ \\
\hline
\end{tabular}

Source: Processed data from Financial Statement of PT GREAT RIVER INTERNATIONAL Tbk. and its subsidiary companies.

Table 9 shows that the company succeeded in creating added value for the owner of capital, in accordance with the aim of maximising the value of the company or increasing the investor's prosperity, that is of Rp. 2,726,421,274.28.- 
Table 10 EVA calculation of PT TOKO Gunung Agung Tbk and its Subsidiary Companies per December 312005 (In Rupiah)

\begin{tabular}{cccccc}
\hline \multirow{2}{*}{ Year } & NOPAT & Invested Capital & WACC & Capital Charges & EVA \\
\cline { 2 - 6 } & $\mathbf{( 1 )}$ & $\mathbf{( 2 )}$ & $\mathbf{( 3 )}$ & $\mathbf{( 4 ) = ( 2 ) \times ( 3 )}$ & $\mathbf{( 5 ) = ( 1 ) - ( 4 )}$ \\
\hline 2005 & $4.341 .158 .012,00$ & $34.067 .982 .814,00$ & $15.268 \%$ & $5.201 .523 .463,63$ & $(860.365 .451,63)$ \\
\hline
\end{tabular}

Source: Processed data from Financial Statement of PT TOKO GUNUNG AGUNG Tbk. and its subsidiary companies

Table 10 shows that the value of the company decreased as resulting from the recovery rate that was produced lower than the level of return demanded by the investors, that is in the amount of Rp (860.365.451,63,-).

Table 11 EVA calculation of PT SONA TOPAS TOURISM INDUSTRY Tbk and its Subsidiary Companies per December 312005 (In Rupiah).

\begin{tabular}{cccccc}
\hline \multirow{2}{*}{ Year } & NOPAT & Invested Capital & WACC & Capital Charges & EVA \\
\cline { 2 - 6 } & $\mathbf{( 1 )}$ & $\mathbf{( 2 )}$ & $\mathbf{( 3 )}$ & $\mathbf{( 4 )}=\mathbf{( 2 )} \mathbf{x}(\mathbf{3})$ & $\mathbf{( 5 ) = ( 1 ) - ( 4 )}$ \\
\hline 2005 & $32.311 .868 .104,00$ & $290.657 .857 .878,00$ & $9.443 \%$ & $27.445 .368 .230,13$ & $4.866 .499 .873,87$ \\
\hline
\end{tabular}

Source: Processed data from Financial Statement of PT SONA TOPAS TOURISM INDUSTRY Tbk. and its subsidiary companies

Table 11 shows that the company succeeded in creating added value for the owner of capital, in accordance with the aim of maximising the value of the company or increasing the investor's prosperity, that is of Rp. 4,866,499,873.

\section{The comparison of Eva Method with ROA Method}

\section{EVA Method}

Based on results of Eva method calculation for 10 retail trade companies registered in BEJ, suggestion of investment is shown in Table 11

Table 11 Results of the Calculation of EVA method for 10 Retail Trading companies in BEJ (in Rupiah)

\begin{tabular}{clrc}
\hline No & \multicolumn{1}{c}{ The name of the Company } & Eva's value & $\begin{array}{c}\text { The Decision suggestion } \\
\text { of Investment }\end{array}$ \\
\hline 1 & PT Rimo Catur Lestari Tbk. & $(3.998 .360 .323,18)$ & No \\
2 & PT Ramayana Lestari Sentosa Tbk. & $214,627.790 .000,00$ & Yes \\
3 & PT Mitra Adiperkasa Tbk & $59.084 .504,69$ & Yes \\
4 & PT Metro Supermarket Realty Tbk. & $(7.591 .442 .847,13)$ & No \\
5 & PT Matahari Putra Prima Tbk & $168.245 .240 .000,00$ & Yes \\
6 & PT Alfa Retailindo Tbk. & $9.397 .561 .588,52$ & Yes \\
7 & PT Hero Supermarket Tbk. & $(9.481 .220 .000,00)$ & No \\
8 & PT Great River International Tbk & $2.726 .421 .274,28$ & Yes \\
9 & PT Toko Gunung Agung Tbk. & $(860.365 .451,63)$ & No \\
10 & PT Sona Topas Tourism Industry Tbk. & $4.866 .499 .873,87$ & Yes \\
\hline
\end{tabular}

Source: Hasil Pengolahan Penulis. 
By using Eva method, it is suggested to invest in 6 retail trade companies, namely PT Ramayana Lestari Sentosa Tbk., PT Mitra Adiperkasa Tbk., PT Matahari Putra Prima Tbk., PT Alfa Retailindo Tbk., PT Great River International Tbk., and PT Sona Topas Tourism Industry Tbk.

\section{ROA Method}

Based on data from BEJ, the results are shown in Table 12.

Table 12 Results of the ROA Value Calculation of 10 Retail Trading companies in BEJ

\begin{tabular}{clrc}
\hline No & \multicolumn{1}{c}{ The name of the Company } & $\begin{array}{c}\text { The ROA value } \\
(\mathbf{\% )}\end{array}$ & $\begin{array}{c}\text { The Decision suggestion } \\
\text { of Investment }\end{array}$ \\
\hline 1 & PT Rimo Catur Lestari Tbk. & $-9,2$ & No \\
2 & PT Ramayana Lestari Sentosa Tbk. & 12,93 & Yes \\
3 & PT Mitra Adiperkasa Tbk & 6,86 & Yes \\
4 & PT Metro Supermarket Realty Tbk. & 4,80 & Yes \\
5 & PT Matahari Putra Prima Tbk & 4,86 & Yes \\
6 & PT Alfa Retailindo Tbk. & 1,38 & Yes \\
7 & PT Hero Supermarket Tbk. & 3,66 & Yes \\
8 & PT Great River International Tbk & 0 & No \\
9 & PT Toko Gunung Agung Tbk. & 0,27 & Yes \\
10 & PT Sona Topas Tourism Industry Tbk. & 1,01 & Yes \\
\hline
\end{tabular}

Source: Processed Data

With ROA method, investment suggestion is more often to Eva method, namely as 8 companies, that is PT Ramayana Lestari Sentosa Tbk., PT Mitra Adiperkasa Tbk., PT Metro Supermarket Realty Tbk., PT Matahari Putra Prima Tbk., PT Alfa Retailindo Tbk., PT Hero of the Tbk. Supermarket, PT Toko Mount Agung Tbk. and PT Sona Topas Tourism Industry Tbk, whereas PT Rimo Catur Lestari Tbk. and PT Great River International Tbk. have negative and zero ROA respectively, therefore not suggested for investment.

\section{CONCLUSION}

From analysis results of the research, it could be concluded that the comparison of decision of investment by using EVA (Economic Value Added) method and ROA (Return on Assets) method for registered retail trade company in BEJ during 2005 yielded different results. By using Eva method, there are 6 retail trade companies suggested for investment, namely: PT Ramayana Lestari Sentosa Tbk., PT Mitra Adiperkasa Tbk., PT Matahari Putra Prima Tbk., PT Alfa Retailindo Tbk., PT Great River International Tbk., and PT Sona Topas Tourism Industry Tbk. Whereas by using ROA method, there are 8 retail trade companies that were suggested, namely: PT Ramayana Lestari Sentosa Tbk., PT Mitra Adiperkasa Tbk., PT Metro Supermarket Realty Tbk., PT Matahari Putra Prima Tbk., PT Alfa Retailindo Tbk., PT Hero of the Tbk. Supermarket, PT Toko Gunung Agung Tbk. and PT Sona Topas Tourism Industry Tbk. Investment on PT Ramayana Lestari Sentosa Tbk., PT Mitra Adiperkasa Tbk., PT Matahari Putra Prima Tbk., PT Alfa Retailindo Tbk. and PT Sona Topas Tourism Industry Tbk. is highly suggested since the company does not only consider profits but also give attention to the interests of the investors. 


\section{Suggestions and Further Research}

Suggestions related to the conclusion of this research are: (1) Retail trade companies should pay more attention in creating added value for investors; (2) EVA method is recommended in measuring company achievements, specifically creation of added value; (3) Investors should invest in companies with high return on investment; (3) Further researches should use better samples in more various fields; (4) Observation period should be set longer to obtain more generalized data:

\section{REFERENCES}

Emery, D., Finnerty, J., dan Stowe, J. (2004) Corporate Financial Management 2/e, Pearson Higher Education.

Gunawan, Lily. (2005). Analisis Kinerja Keuangan PT Hanjaya Mandala Sampoerna Tbk. Tahun 2001-2003. Penerbit: Universitas Bina Nusantara. Jakarta.

Indriantoro, N. \& Supomo, B., (2002) Metodologi Penelitian Bisnis Untuk Akuntansi dan Manajemen, Edisi Pertama, BPFE., Yogyakarta.

Ikatan Akuntan Indonesia. Standar Akuntansi Keuangan. Jakarta: Salemba Empat. 2004.

Karels, G. and A. Prakash. 1987. Multivariate normality and forecasting of business bankruptcy. Journal of Business Finance \& Accounting 14(4): 573-593. 